\title{
A Study Of Renal Function Test, Liver Function Test, ECG Changes And Their Prognostic Outcome In The Patients Of Japanese Encephalitis In Jharkhand
}

\author{
Dr Diljeet Bodra, Dr Yuvraj Lahre**, Dr Punam K Munda ${ }^{* * *}$ \\ Department Of Medicine Rajendra Institute Of Medical Sciences Ranchi \\ DOI: 10.29322/IJSRP.10.05.2020.p10144 \\ http://dx.doi.org/10.29322/IJSRP.10.05.2020.p10144
}

\begin{abstract}
Background and objectives :Japanese Encephalitis is a mosquito borne disease and leading cause viral encephalitis in India. In INDIA, the states which has high number of cases are UTTAR PRADHESH > ASSAM > BIHAR > KARNATAKA...etc. It usually affect the low socio-economic people and rural areas. We present the Renal Function Test, Liver Function Test , Ecg Changes and Their prognostic Outcome in the patient of Japanese Encephalitis In Jharkhand. Methods : This Study was done on 18 Japanese Encephalitis which was confirmed through CSF IgM $\mathrm{Ab}$ in the Microbiology department of RIMS Ranchi. The Renal profile, Liver profile and Ecg Changes were studied. Results : Out of 18 Patients, 27.77\% of cases had serum creatinine $>2.1 \mathrm{mg} / \mathrm{dl}$. About $22.22 \%$ cases came under $1.1-2 \mathrm{mg} / \mathrm{dl}$ of serum creatinine group. And about $50 \%$ of cases had serum creatinine $<1 \mathrm{mg} / \mathrm{dl}$. About $5.55 \%$ of cases had total bilirubin $>2.1 \mathrm{mg} / \mathrm{dl}$, about $33.33 \%$ of cases had total bilirubin between $1.1-2 \mathrm{mg} / \mathrm{dl}$ and $61.11 \%$ had total bilirubin $<1$ $\mathrm{mg} / \mathrm{dl}$. About 33.33\% cases had LAD (Left Axis Deviation), 16.66\% cases had RAD( Right Axis Deviation) and $50 \%$ cases were normal. Out of $18 \mathrm{JE}$ patients, 14 patients were discharged and 4 were dead. Conclusion : According to data collected in our study, we further recommend more studies on these parameters for better prognosis and outcome in the patient of Japanese Encephalitis.
\end{abstract}

Index Terms- Japanese Encephalitis, Renal Function Test, Liver Function Test, Ecg Changes , Prognostic Outcome, Jharkhand

\section{INTRODUCTION}

$\mathrm{J}$ apanese Encephalitis is a mosquito borne flavivirus disease which is most commonly found in South Asian countries. It is usually start with fever, headache, nausea and vomiting. After prolonged fever of 2 weeks altered sensorium start, which is sign of aseptic meningitis. The source of infection is irrigated rice field. Most common mosquito associated with JE is Culex Tritaeniorhynchus. Amplifying agents are pigs and horses. Vaccination in amplifying agent will definitely reduce the growth of virus. The main objective of the study were to find out the Renal - Liver - ECG changes in the patients of Japanese Encephalitis.

\section{Pathogen}

The family Flaviviridae contains only one genus, Flavirus. They are smaller than alphaviruses, being $40 \mathrm{~mm}$ in diameter. The name Flavirus refers to the yellow fever virus ( flavus in Latin means yellow) [1]. Flavivirus sensu stricto have single stranded positive sense RNA genomes (11KB) and form spherical enveloped particles $40-60 \mathrm{~nm}$ in diameter. Vectors are usually infected when they feed on viremic hosts; humans are accidental hosts who usually are infected by arthropod bites [2] .

\section{Epidemiological Pattern Indian Setting}

In India, Japanese Encephalitis was first recognized in 1955 when the virus was isolated from mosquitoes of the Culex Vishnui complex from Vellore during outbreak of encephalitis in Tamil Nadu [3] - It usually common in children. Most of the cases occur in rainy season I.e around July to October. 


\section{Diagnosis}

1. The ideal method for laboratory confirmation is testing cerebrospinal fluid ( CSF ) or serum for JEV specific IgM antibody.

2. Plaque reduction neutralization test.

3. Virus Isolation.

4. Nucleic Acid amplification

\section{Vaccine}

The Russian were the first to practice vaccination against JE. In the United States Army and resulted in the vaccination of over 250000 persons on Okinawa in 1945 and 1946 [4]. There are two strain of vaccine - (1) formalin inactivated mouse brain vaccine using - NAKAYAMA STRAIN. It is given as two doses at two weeks apart which is followed by a booster 6-12 months . (2) Live Attenuated Vaccine developed in China from JE strain SA - 14-14-2. It is given as two doses at 1 year apart.

\section{Vaccines Licensed In India}

1. Inactivated vero cell culture derived SA $14-14-2$

2. Inactivated vero cell culture derived Kolar Strain, 821564XY, JE vaccine [5]

\section{Material And Methods}

\section{Study Population Source Of Data}

The study was conducted on 18 consecutive patients admitted to Rajendra Institute of Medical Sciences, Ranchi during the study period.

\section{INCLUSION CRITERIA}

JE patients is diagnosed by : clinically

Blood Analysis

Biochemical Methods

CSF Findings

\section{Exclusion Criteria}

Patients with :

1. Diabetes

2. Hypertension

3. Previous Heart Illness

4. Lung Pathology

5. Sepsis

6. Autoimmune Disease

\section{Investigation}

1. Complete Blood Count

2. Liver Function Test

3. Renal Function Test

4. CSF Finding

5. Ecg

\section{Design Of Study}

Observational And Hospital Based Prospective Study.

Period Of Study

One year and Two month Study ( $1^{\text {st }}$ July 2018 to $1^{\text {st }}$ September 2019)

\section{Collaborating}

Department

Department of microbiology

Department of pathology

Department of Biochemistry 
Consent : Individual/care takers written and informed consent

Analysis : Statistical Analysis was performed using appropriate tests as required according to data.

Conflict Of Interest : NIL

Financial Support: SELF

Participants : 18 JAPANESE ENCEPHALITIS Patients admitted in Medicine ward at Rajendra Institute of Medical Sciences Ranchi

\section{Observations And Result}

\begin{tabular}{|c|c|c|}
\hline SEX & NO. OF CASES & PERCENTAGE \\
\hline MALE & 17 & 94.44 \\
\hline FEMALE & 1 & 5.55 \\
\hline
\end{tabular}

TABLE 1 : Distribution Of Age

\section{Comments :}

About 50\% Of The Study Population Were In The Group Of $21-40$ Years. Rest Were Below Fifty Percentage . About 22.22\%, 16.66\% And 11.11\% Were From $41-60$ Year, <20 Years And > 61 Years Of Age Group Respectively.

\begin{tabular}{|l|c|c|}
\hline ECG & NO. OF CASES & PERCENTAGE (\%) \\
\hline NORMAL & 9 & 50 \\
\hline LAD & 6 & 33.33 \\
\hline RAD & 3 & 16.66 \\
\hline
\end{tabular}

TABLE 2 : Sex distribution In The Study Population

Comments : About $94.44 \%$ Were Male And 5.55\% Were Female

TABLE 3 : Ecg Changes In The Study Population

\begin{tabular}{|l|c|l|}
\hline $\begin{array}{l}\text { SERUM } \\
\text { CREATININE(MG/DL) }\end{array}$ & NO. OF CASES & PERCENTAGE (\%) \\
\hline$<1$ & 9 & 50 \\
\hline $1.1-2$ & 4 & 22.22 \\
\hline$>2.1$ & 5 & 27.77 \\
\hline
\end{tabular}

Comments : About 33.33\% Had LAD, 16.66\% Had RAD And 50\% Cases Had Normal Ecg

TABLE 4 : Serum Creatinine In The Study Population

Comments: About 50\% Of Cases $\mathrm{Had}<1 \mathrm{mg} / \mathrm{dl}$ Serum Creatinine. About $27.77 \%$ Of Cases Had Serum Creatinine > $2.1 \mathrm{mg} / \mathrm{dl}$ And $22.22 \%$ Of Cases Had Serum Creatinine Between 1.1 - $2 \mathrm{mg} / \mathrm{dl}$ [ normal male : $0.6-1.2 \mathrm{mg} / \mathrm{dl}$ and female : $0.5-0.9 \mathrm{mg} / \mathrm{dl}$ ] [6] 


\begin{tabular}{|c|c|c|}
\hline TOTAL BILIRUBIN (MG/DL) & NO. OF CASES & PERCENTAGE (\%) \\
\hline $0-1$ & 11 & 61.11 \\
\hline $1.1-2$ & 6 & 33.33 \\
\hline$>2.1$ & 1 & 5.55 \\
\hline
\end{tabular}

TABLE 5 : Total Bilirubin In The Study Population

Comments : About $61.11 \%$ Were From $0-1 \mathrm{mg} / \mathrm{dl}$ Of Total Bilirubin Group. About 33.33

$\%$ Were From 1.1-2 mg/dl Of Total Bilirubin Group And 5.55\% Were From > $2.1 \mathrm{mg} / \mathrm{dl}$

Total Bilirubin Group. [ normal total bilirubin: $0.3-1.3 \mathrm{mg} / \mathrm{dl}$ ] [7]

TABLE 6: Outcome Distribution In The Study Population

\begin{tabular}{|c|c|c|}
\hline OUTCOME & NO. OF CASES & PERCENTAGE (\%) \\
\hline DISCHARGE & 14 & 77.77 \\
\hline DEATH & 4 & 22.22 \\
\hline
\end{tabular}

Comments : About $77.77 \%$ Of Cases Were Discharged And 22.22\% Were Dead

TABLE 7 : Death Vs Rft

\begin{tabular}{|c|c|c|}
\hline $\begin{array}{c}\text { SERUM } \\
\text { MG/DL }\end{array}$ & NO. OF DEAD CASES & PERCENTAGE (\%) \\
\hline $0-1.9$ & 1 & 25 \\
\hline$>2$ & 3 & 75 \\
\hline
\end{tabular}

Comments : About $75 \%$ Of Dead Had Serum Creatinine - > $2 \mathrm{mg} / \mathrm{dl}$

TABLE 8: Death VS Lft

\begin{tabular}{|c|c|c|}
\hline TOTAL BILIRUBIN MG/DL & NO. OF DEAD CASES & PERCENTAGE(\%) \\
\hline $0-1$ & 1 & 25 \\
\hline$>1$ & 3 & 75 \\
\hline
\end{tabular}

Comments : About 75\% Of Dead Cases Had Total Bilirubin > $1 \mathrm{mg} / \mathrm{dl}$

TABLE 9: Death vs Ecg

\begin{tabular}{|c|c|c|}
\hline ECG & NO. OF DEAD CASES & PERCENTAGE(\%) \\
\hline NORMAL & 0 & 0 \\
\hline LAD & 4 & 100 \\
\hline RAD & 0 & 0 \\
\hline
\end{tabular}

Comments : About $100 \%$ Of Dead Cases Had LAD Axis In Ecg 


\section{Discussion}

In total of $18 \mathrm{JE}$ patients, about $50 \%$ of the study population were in the group of $21-40$ years. About $22.22 \%$ of the study population were in the group of $41-60$ years and $16.66 \%$ in the <20 years of age group. All 18 patients came with the complain of fever, $72.22 \%$ people were complaining of headache and $50 \%$ cases had altered sensorium. All 18 patients were tested positive for CSF JE IgM.

About $27.77 \%$ of cases had serum creatinine $>2.1 \mathrm{mg} / \mathrm{dl}$. About $22.22 \%$ cases came under $1.1-2 \mathrm{mg} / \mathrm{dl}$ of serum creatinine group. And about $50 \%$ of cases had serum creatinine $<1 \mathrm{mg} / \mathrm{dl}$. About $5.55 \%$ of cases had total bilirubin $>2.1$ $\mathrm{mg} / \mathrm{dl}$, about $33.33 \%$ of cases had total bilirubin between $1.1-2 \mathrm{mg} / \mathrm{dl}$ and $61.11 \%$ had total bilirubin $<1 \mathrm{mg} / \mathrm{dl}$. About $33.33 \%$ cases had LAD ( Left Axis Deviation), $16.66 \%$ cases had RAD (Right Axis Deviation) and $50 \%$ cases were normal. Out of 18 JE patients, 14 patients were discharged and 4 were dead.

Out of 4 dead patients, 3 patients had serum creatinine $>2 \mathrm{mg} / \mathrm{dl}$, which was about $75 \%$ among dead.

Three dead patient had total bilirubin $>1 \mathrm{mg} / \mathrm{dl}$ which was about $75 \%$ among dead. All 4 dead patients had Left Axis Deviation ( LAD ).

\section{Conclusion}

The incidences of JE has been increased in adults in recent years. Studies to assess the cause of epidemiological shift, control of amplifying host, awareness programmes, health education and more targeted use of JE vaccination are need of the hour to reduce mortality and morbidity of JE among adults.

According to data collected in our study, we further recommend more studies on these parameters for better prognosis and outcome in the patient of Japanese Encephalitis.
Abbreviation
1. LAD - LEFT AXIS DEVIATION
2. RAD - RIGHT AXIS DEVIATION
3. RFT - RENAL FUNCTION TEST
4. LFT - LIVER FUNCTION TEST
5. ECG - ELECTROCARDOGRAPHY
6. JE- JAPANESE ENCEPHALITIS
7. CSF- CEREBEROSPINAL FLUID

\section{Acknowledgement}

We have been able to work on and complete this article, I would like to sincerely thank everyone who has been instrumental in making it a possible.

Words fail to express my deep sense of gratitude towards my guide Prof Dr. Umesh Prasad ( DTMH, MD General Medicine ) for his unfailing belief in me. We have been blessed to work under his guidance and learnt lots of things from him. He encouraged and guided me from the inception of this project in 2018 till the very end and without whom it could not have come to fruition.

We want to thank our family for inspiring us to push our limit. Last but not the least I would thank all the patients of the study who served as the backbone and without their sipport the study would have been possible .

Thank you
1. Dr Diljeet Bodra
MD Gen Medicine
Rims Ranchi
2. Dr Yuvraj Lahre
MD Gen Medicine Rims Ranchi
3. Dr Punam k Munda
MD Gen Medicine
Rims Ranchi

\section{REFERENCES}

[1] Ananthanarayan and Panikers Textbook of Microbiology 10th Edition.p-526

[2] Harrison Internal Medicine 20th edition.p $(1490,1495)$

[3] Ananthanarayan and Panikers Textbook of Microbiology 10th Edition.p-527

[4] John mackenzie, ADT Barett,, V deubel. Japanese Encephalitis and West Nile Vrus 2012 p27

[5] Ananthanarayan and Panikers Textbook of Microbiology 10th Edition.p-528

[6] Harrison Internal Medicine 19th edition.p2759 
[7] Harrison Internal Medicine 19th edition.p2758

\section{AUTHORS}

First Author - Dr Diljeet Bodra , MD General Medicine, Rims Ranchi , dude.rocky098@gmail.com

Second Author - Dr Yuvraj Lahre , MD General Medicine, yuvi.10170@gmail.com

Third Author - Dr Punam K Munda , MD General Medicine , priyafriends6@gmail.com

Corresponding Author - Dr Diljeet Bodra , MD General Medicine , Rims Ranchi , dude.rocky098@gmail.com, PH : +919199377815 